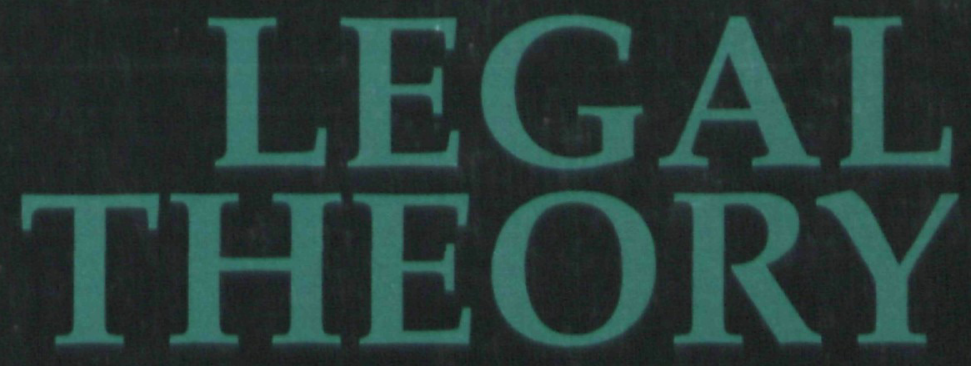

\title{
Volume 1 \\ Number 4
}

\section{December 1995}

\section{CAMBRIDGE UNIVERSITY PRESS}




\title{
EDITORS
}

\author{
Larry Alexander, University of San Diego School of Law \\ Jules L. Coleman, Yale Law School \\ Frederick Schauer, Harvard University, John F. Kennedy School of Government
}

\section{EDITORIAL BOARD}

Bruce Ackerman, Yale University

Robert Alexy, University of Kiel

Anita Allen, Georgelown University

Lea Brilmayer, New York Universily

Ruth Chang, University of Califormia, Los Angeles

Robert Cooter, University of California, Berheley

Richard Craswell, University of Chicago

Meir Dan-Cohen, Universily of California, Berkely

Antony Duff, Stirling University

Gerald Dworkin, University of lllinois, Chicago

Ronald Dworkin, New York Unjuersity; Oxford

University

Robert Ellickson, Yale Law School

Joel Feinberg, University of Arizona

John Finnis, Oxford University

Ruth Gavison, Helrew Universily

Kent Greenawalt, Columbia University

Thomas Grey, Sianford University

Michael Hechter, University of Arizona

Douglas Heckathorn, University of Connecticul

Risto Hilpinen, Turku University

Heidi Hurd, University of Pennsylvania

Frances Kamm, New York University

Louis Kaplow, Harvand University

Mark Kelman, Stanfond University

Lewis Kornhauser, New York University

Jody Kraus, University of Virginia

Brian Leiter, University of Texas, Austin
Saul Levmore, University of Vinginia

David Lyons, Baston University

Neil MacCormick, Edinbungh University

Andrei Marmor, University of

Tel Aviv

Frank Michelman, Harvard University

Michael Moore, University of Pennsyluania

Stephen Munzer, University of California, Los

Angeles

Jefrie Murphy, Arizona State University

Stephen Perry, University of Pennslvania

Gerald Postema, University of North Caralina

Margaret Jane Radin, Stanford University

Joseph Raz, Oxford University

Donald Regan, University of Michigan

Janet Radcliffe Richards, The Open University, $U K$

Carol Rose, Yale University

Roger Shiner, University of Alberta

Walter Sinnott-Armstrong. Dartmouth College

Patricia Smith, University of Kentucky

Cass Sunstcin, University of Chicago

Coaba Varga, Budapest University

Jeremy Waldron, Princeton University

Steven Walt, University of Vinginia

Wil Waluchow, McMaster University

Richard Wasserstrom, Uniuersity of California,

Santa Cruz

Alan Wertheimer, University of Vermont

Robin West, Georgetown University

Editorial Office: Lgal Theory, Yale Law School, Drawer 401A Yale Station, New Haven, Connecticut 06520, USA; Fax: 203-432-8260.

Publishing, Subscription, and Advertising Orfices: Cambridge Univerity Press, 40 West 20th Street, New York NY 10011; or Cambridge University Press, The Edinburgh Building, Shaftesbury Road, Cambridge CB2 2RU, England.

$L \mathrm{~g}$ al Theory is published quarterly. Annual subscription rates for Volume 1:,1995: Institutions: $\$ 100.00$ in the USA, Canada, and Mexjco; UKf62.00 in all other countries. Individuals: $\$ 50.00$ in the USA, Canada, and Mexico; UKf31.00 in all other countries. Prices include postage and insurance; airmail outside the USA, Cr.s.:?, ind Mexico is 520.00 extra.

Copyright 01996 Cambridge University Press. All rights reserved. No part of this publ. Eaticn may be reproduced, in any form or by any means, electronic, photocopying or otherwise, without permissicn tro: Cambridge University Press. Photocopying information for users in the USA. The Item-Fee Code for this publication (1352-3252/96 \$7.50 +.10 ) indicates that copying for internal or personal we beyond that permitted by Sec. 107 or 108 of the US Copyright Law is authorized for users duly registered with the Copyright Clearance Center (CCC) Transaction Reporting Service, provided that the appropriate remittance of $\$ 7.50$ per article is paid directly to: CCC, 222 Rosewood Drive, Danvers, MA 01923. Specific written permission must be obtained from Cambridge University Press for all other copying. Contact the ISI Tearsheet Service, 3501 Market Street, Philadelphia, PA 19104, for single copies of separate articles.

Second-class postage paid at New York, NY, and additional mailing offices. Forw a in and Return Postage Guaranteed. Address Correction Requested. Postmaster: Send address changes in $t, r$. . and Canada to: Logl Theory, Cambridge University Press, Journals Fulfillment Dept, 110 Midland Ave., Pa. : '.,-ster, NY 10579-4930.

Printed in the United States of America. 